\title{
HUBUNGAN POLA ASUH OTORITER DENGAN HARGA DIRI SISWA KELAS XI DI SMA NEGERI 3 BINJAI TAHUN AJARAN 2016/2017
}

\author{
Christina, Dina Hidayani Hts, Juwita Erdaini \\ STKIP Budidaya Binjai
}

\begin{abstract}
Abstrak
Harga diri merupakan evaluasi individu terhadap dirinya sendiri baik secara positif atau negatif. Harga diri yang positif akan membangkitkan rasa percaya diri, penghargaan diri, rasa yakin akan kemampuan diri, rasa berguna serta rasa bahwa kehadirannya diperlukan di dunia ini. Sebaliknya, seorang remaja yang memiliki harga diri yang negatif akan cenderung merasa bahwa dirinya tidak mampu dan tidak berharga, cenderung takut menghadapi respon dari orang lain, tidak mampu membina komunikasi yang baik dan cenderung merasa hidupnya tidak bahagia. Berdasarkan rumusan penelitian di atas, maka yang menjadi tujuan penelitian ini adalah untuk mengetahuai apakah ada hubungan pola asuh otoriter dengan harga diri siswa kelas XI di SMA Negeri 3 Binjai. Penelitian ini yaitu penelitian yang memakai angket yang merupakan cara pengumpulan data dengan memberikan pertanyaan kepadaa responden untuk di isi. Berdasarkan hasil analisis menunjukkan bahwa untuk nilai signifikansi $(\mathrm{P})$ antara variabel pola asuh otoriter dengan variabel harga diri siswa sebesar 0,001 . Karena $\mathrm{P}<0,05$, maka hal ini berarti hipotesis penelitian diterima atau terdapat hubungan pola asuh otoriter dengan harga diri pada siswa kelas XI di SMA Negeri 3 Binjai Tahun Pelajaran 2016/2017. Dimana pola asuh otoriter adalah tingkat penilaian yang positif atau negatif yang dihubungkan dengan harga diri seseorang. Harga diri merupakan evaluasi seseorang terhadap dirinya sendiri secara positif dan juga sebaliknya dapat menghargai secara negatif. Sehingga kesimpulan dari penilitian ini adalah ada hubungan yang signifikan antara pola asuh otoriter dengan harga diri siswa kelas XI di SMA Negeri 3 Binjai tahun ajaran 2016/2017.
\end{abstract}

kata kunci : pola asuh otoriter, harga diri

\section{PENDAHULUAN}

Pada fase perkembangan manusia, masa remaja merupakan pusat perhatian. Hal ini disebabkan karena masa remaja merupakan masa transisi dari masa kanak-kanak ke masa dewasa. Dalam pengertian lain sebagaimana dijelaskan yaitu remaja adalah manusia yang sedang berada pada satu periode kehidupan puber tepatnya ketika seseorang berada pada masa transisi antara masa kanak-kanak dan masa pemulaan dewasa. Masa transisi ini sering kali menghadapkan individu yang bersangkutan kepada situasi yang membingungkan, disatu pihak ia masih kanak-kanak, tetapi dipihak lain ia harus bertindak seperti orang dewasa.

Secara umum membagi masa remaja menjadi tiga bagian, yaitu masa remaja awal, masa remaja pertengahan, dan masa remaja akhir. Masa remaja awal (usia 12-15 tahun) pada masa ini individu mulai meninggalkan peran sebagai anak-anak. Masa remaja pertengahan (usia 15-19 tahun) masa ini ditandai dengan berkembangnya kemampuan berfikir yang baru. Pada masa ini teman sebaya masih berperan penting namun individu sudah lebih mampu 
mengarahkan diri sendiri (self directed). Masa remaja akhir (usia yang diwujudkan dalam bentuk 19-22 tahun) masa ini ditandai oleh persiapan akhir untuk memasuki peran-peran orang dewasa.

Terjadinya proses perubahan dan interaksi antara beberapa aspek yang berubah selama masa remaja. Pertama, perubahan fisik, adalah perubahan biologis dan fsiologis yang berlangsung pada masa pubertas atau pada masa awal remaja, yaitu sekitar umur 11-15 tahun pada wanita dan 12-16 tahun pada pria. Kedua, perubahan emosional, yaitu akibat langsung dari perubahan fisik dan hormonal. Ketiga, perubahan kognitif, perubahan dalam kemampuan berfikir. Keempat, implikasi psikososial, adalah semua perubahan yang terjadi dalam kurun waktu yang singkat itu membawa akibat bahwa fokus utama dari perhatian remaja adalah dirinya sendiri.

Harga diri adalah tingkat penilaian yang positif atau negatif yang dihubungkan dengan konsep diri seseorang. Harga diri merupakan evaluasi seseorang terhadap dirinya sendiri secara positif dan juga sebaliknya dapat menghargai secara negatif. Mengatakan apabila seseorang memiliki taraf harga diri tinggi, maka ia dapat menyusun konsep diri yang positif yang berkaitan dengan aktualisasi diri dan begitupun sebaliknya dengan seseorang yang memiliki taraf harga diri rendah. Orangtua mempunyai pengaruh yang cukup besar bagi perkembangan remaja, dimana orang tua sebagai akibat dari perilaku menyimpang yang dilakukan para remaja. Hasilnya, hukuman hanya akan menimbulkan efek jera sesaat bagi mereka merupakan lingkungan sosial pertama yang meletakkan dasar-dasar kepribadian remaja.

Tiga tipe pola asuh yang dikaitkan dalam aspek-aspek yang berbeda dalam perilaku sosial anak. Pola asuh otoriter adalah suatu gaya pengasuhan membatasi dan menghukum yang menuntut anak untuk mengikuti perintah-perintah orang tua. Pola asuh otoritatif (demokratif) adalah gaya pengasuhan yang mendorong anak-anak agar mandiri tetapi masih menetapkan batas-batas dan pengendalian atas tindakan-tindakan anak. Dan pola asuh laissezfaire (permisif) adalah gaya pengasuhan pembiaran. Ketiga pola asuh ini memberikan sumbangan dalam mewarnai perkembangan terhadap harga diri anak terlebih lagi pada remaja.

SMA Negeri 3 Binjai adalah sekolah yang berada di Jl. Padangsidempuan No. 24, Rambung Barat, Binjai Selatan, Binjai, Sumatera Utara. Sekolah ini berada di dalam sebuah gang kecil yang cukup padat akan penduduk. Hasil studi pendahuluan yang dilakukan melalui wawancara pada 10 siswa, 3 orang mengatakan orang tuanya mempunyai sikap yang keras, suka memberi perintah. 
Harga diri rendah dapat diatasi dengan memberi kesempatan remaja untuk berhasil, memberi pengakuan dan pujian terhadap apa yang dikerjakannya. Tidak memberi tugas yang tidak dapat diselesaikan, serta tidak memberi hukuman pada remaja. Menanamkan gagasan yang dapat memotivasi kreatifitas anak untuk berkembang, mendukung aspirasi yang penting sebagai pembimbing siswa dalam positif atau cita-cita remaja sehingga mereka memandang dirinya bermakna. Serta, menanggapi pertanyaan dan tanggapan anak dengan memberi penjelasan yang sesuai.

Berdasakan latar belakang di atas maka peneliti tertarik untuk melakukan penlitian "Hubungan Pola Asuh Otoriter dengan Harga Diri Siswa Kelas XI di SMA Negeri 3 Binjai Tahun Ajaran 2016/2017’'.

\section{METODE PENELITIAN}

Penelitian ini akan dilaksanakan di SMA Negeri 3 BinjaiJalan Padang SidempuanNomor 24 Binjai. Kegiatan penelitian direncanakan dilakukan Februari 2017 Maret 2017 pada semester genaptahunpelajaran 2016/2017.

Menurut Sugiyono yang dimaksud dengan“ Populasi adalah wilayah generalisasi terdiri atas objek/subjek yang mempunyai kualitas dan karakteristik tertentu. Ditetapkan oleh peneliti untuk dipelajari dan kemudian ditarik kesimpulan". Populasi dalam penelitian ini adalah siswa remaja pria dan wanita yang duduk dikelas XI SMANegeri 3 BinjaiTahun Pelajaran 2016/2017 dengan jumlah keseluruhan 227 orang.

Menurut Sugiyono, "Sampel merupakan sebagian dari jumlah dan karakteristik yang dimiliki oleh populasi." Sedangkan sampel menurut Arikunto adalah sebagian atau wakil populasi yang akan”. Dalam penelitian ini peneliti mengambil 1 kelas yaitu kelas XI IPS 1 sebagai sampel sebanyak 42 orang siswa. Dikarenakan kelas ini memiliki ciri-ciri untuk dapat diteliti.

Dalam penelitian ini jenis penelitian yang digunakan yaitu penelitian kuantitatif yang bertujuan untuk menemukan ada tidaknya hubungan antara variabel satu dengan variabel lainnya. Penelitian ini menggunakan data-data numeric atau angka yang di olah dengan metode statistic, setelah diperoleh hasilnya kemudian dideskripsikan dengan menguraikan kesimpulan yang didasari oleh angka dengan metode statistic tersebut.Bentuk paradigma dari judul penelitian hubungan antara pola asuh otoriter orang tua dengan harag diri siswa, yaitu:

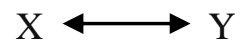

$\mathrm{X}=$ Pola asuh otoriter orang tua

$\mathrm{Y}=$ Harga diri 
Dalam penelitian ini peneliti menggunakan beberapa metode yaitu:

1. Observasi, dimana pada metode ini peneliti mengamati secara langsung kegiatan yang dilakukan oleh siswa tersebut.

2. Kuesioner/angket yaitu sekumpulan daftar pertanyaa atau pernyataanyang tertulis mengenai factual atau opini yang berkaitan dengan diri siswa yang dianggap fakta atau kebenaran yang diketahui dan perlu dijawab oleh siswa.

Skala ini dipakai untuk memperoleh data tentang kemampuan perencanaan karir dan konsep diri yang dijabarkan dalam bentuk kisi-kisi. Siswa diminta untuk memilih satu jawaban yang sesuai dengan keadaan diri dengan cara memberikan tanda ceklis . jawaban setiap item instrument yang menggunakan skala likert terdiri dari pernyataan positif dan pernyataan negatif dengan setiap pernyataan terdiri dari 4 alternatif pilihan jawaban yang berbeda. Format bobot penskoran terhadap jawaban siswa sebagai berikut: Sangat Setuju (SS) memiliki skor 4, Setuju (S) memiliki skor 3, Tidak Setuju (TS) memiliki skor 2, dan Sangat Tidak Setuju ( STS) memiliki skor 1.

\section{HASIL DAN PEMBAHASAN}

Penelitian ini dilakukan di kelas XI SMA Negari 3 Binjai. Subjek penelitian (populasi)pada penelitian adalah semua siswa dari kelas XI tahun pelajaran 2016/2017 yang berjumlah 227 siswa. Seperti yang sudah dikemukakan pada bab sebelumnya, bahwa dikarenakan jumlah populasi dibawah 100, maka seluruh populasi menjadi sampel dalam penelitian. Dikarenakan jumlah populasi dari penelitian ini lebih dari 100, maka peneliti mengambil $15 \%$ dari total populasi. Oleh karena jumlah sampel sebesar 34 orang, maka peneliti mengambil sebagai jumlah sampel, maka para siswa kelas XI dijadikan sampel.

Berdasarkan hasil penilitian menunjukkan bahwa nilai signifikansi (p) untuk variabel pola asuh otoriter sebesar 0,188 (Kolmogorov-Smirnov) dan 0,494 (Shapiro-Wilk). Sedangkan untuk variabel harga diri siswa verbal nilai p sebesar 0,200 (Kolmogorov-Smirnov) dan 0,871 (Shapiro-Wilk). Karena nilai $\mathrm{p}$ untuk seluruh variabel lebih besar dari 0,05 maka dapat disimpulkan bahwa data pada variabel pola asuh otoriter dan harga diri siswa terdistribusi normal.

Dari hasil analisis menunjukkan bahwa untuk nilai signifikansi $(\mathrm{P})$ antara variabel religiusitas dengan variabel perilaku agresif verbal sebesar 0,001 . Karena $P<0,05$, maka hal 
ini berarti hipotesis penelitian diterima atau terdapathubungan pola asuh otoriter dengan harga diri siswa pada siswa kelas XI di SMA Negeri 3 Binjai Tahun Pelajaran 2016/2017.

Berdasarkan hasil uji normalitas didapatkan bahwa nilai signifikansi (p) untuk variabel pola asuh otoriter sebesar 0,188 (Kolmogorov-Smirnov) dan 0,494 (Shapiro-Wilk). Sedangkan untuk variabel harga diri siswa nilai p sebesar 0,200 (Kolmogorov-Smirnov) dan 0,871 (Shapiro-Wilk). Karena nilai p untuk seluruh variabel lebih besar dari 0,05 maka dapat disimpulkan bahwa data pada variabel religiusitas dan perilaki agresif verbal terdistribusi normal.

Berdasarkanhasil analisis menunjukkan bahwa untuk nilai signifikansi $(\mathrm{P})$ antara variabel pola asuh otoriter dengan variabel harga diri siswa sebesar 0,001. Karena $\mathrm{P}<0,05$, maka hal ini berarti hipotesis penelitian diterima atau terdapathubungan pola asuh otoriter dengan harga diri pada siswa kelas XI di SMA Negeri 3 Binjai Tahun Pelajaran 2016/2017.

Harga diri adalah tingkat penilaian yang positif atau negatif yang dihubungkan dengan konsep diri seseorang. Harga diri merupakan evaluasi seseorang terhadap dirinya sendiri secara positif dan juga sebaliknya dapat menghargai secara negatif. Mengatakan apabila seseorang memiliki taraf harga diri tinggi, maka ia dapat menyusun konsep diri yang positif yang berkaitan dengan aktualisasi diri dan begitupun sebaliknya dengan seseorang yang memiliki taraf harga diri rendah. Orangtua mempunyai pengaruh yang cukup besar bagi perkembangan remaja, dimana orang tua merupakan lingkungan sosial pertama yang meletakkan dasar-dasar kepribadian remaja.

\section{KESIMPULAN}

Berdasarkan hasil analisis dan interpretasi data penelitian dapat ditarik kesimpulan mengenai hasil penelitian yang telah dilakukan, yaitu terdapat hubungan konsep diri dengan perencanaan karir pada siswa kelas XI SMA Abdi Negara Binjai Tahun Pelajaran 2016/2017. Hal ini dikarenakan terdapat nilai signifikasi yang berada dibawah $<0,05$, maka hal ini berarti hipotesis penelitian diterima.

\section{REFERENSI}

Arikunto, Suharsimi. Prosedur Penelitian Suatu Pendekatan Praktik, Jakarta: PT Rineka Cipta, 2010.

2001. Prosedur Penelitian. Jakarta: Rineka Cipta.

Branden, N. 1981. The psychology of Self Esteem, A New Concept of Man's. Psychology 
Nature. Toronto : Bantam Books.

Baron, Robert A. \& Donn Byrne. 2000. Social Psychology (9th edition). USA: Allyn \& Bacon.

Coopersmith, S. 1967. The Antecedent Of Self Esteem. San Fransisco : W.H. Freeman\& Company.

Frey, D\&Carlock, C.J. 1987. Enhancing Self Esteem. Ohio: Accelerated Development.

Kozier, B.B., \& Erb, G. 1987. Fundamentals of Nursing: Concepts and. Procedures (3rd ed). Massachussets: Eddison Wesley.

Moh. Shochib. 2000. Pola Asuh Orang Tua dalam Membantu Anak Mengembangkan Disiplin Diri. Jakarta: Rineka Cipta.

Monks, F.J. dan Knoers, A.M.P. dan Haditono, S.R. 1999. Psikologi. Perkembangan Pengantar dalam Berbagai Bagiannya. Yogyakarta: Gajah Mada University Press.

Notoatmodjo,s. 2007. Metodologi Penelitian Kesehatan. Jakarta : PT Rineka Cipta.

Sugiyono. 1997. Sampel Penelitian. Bandung: Rosda Karya.

Suryabrata, S. 1993. Psikologi Pendidikan. Jakarta: PT. Raja Grafindo Persada.

Wong, D.L. 2008. Buku Ajar Keperawatan Pediatrik Ed. 6. Jakarta: EGC. 